\title{
Characterisation of Bacterial Isolates from Infected Post-Operative Patients in a Malaysian Tertiary Heart Care Centre
}

\author{
Yi Keng Yong ${ }^{1}$, Nicole Ce Mun Wen $\left.{ }^{1}{ }^{(}\right)$, Genieve Ee Chia Yeo ${ }^{1}$, Zhi Xin Chew ${ }^{1}$, Li Li Chan ${ }^{2}$, \\ Noor Zaitulakma Md Zain ${ }^{3}$, Dinesh Kumar Chellappan ${ }^{4}$ (D) and Yun Khoon Liew ${ }^{4, *}$ \\ 1 School of Health Science, International Medical University, Kuala Lumpur 57000, Malaysia; \\ 00000023095@student.imu.edu.my (Y.K.Y.); NICOLE.WENCE@studentimuedu.onmicrosoft.com (N.C.M.W.); \\ GENIEVE.YEO@student.imu.edu.my (G.E.C.Y.); Chew.zhixin@student.imu.edu.my (Z.X.C.) \\ 2 School of Medicine, International Medical University, Kuala Lumpur 57000, Malaysia; lili_chan@imu.edu.my \\ Institut Jantung Negara, Kuala Lumpur 50400, Malaysia; akma@ijn.com.my \\ 4 School of Pharmacy, International Medical University, Kuala Lumpur 57000, Malaysia; \\ Dinesh_Kumar@imu.edu.my \\ * Correspondence: LiewYunKhoon@imu.edu.my
}

check for updates

Citation: Yong, Y.K.; Wen, N.C.M.; Yeo, G.E.C.; Chew, Z.X.; Chan, L.L.; Md Zain, N.Z.; Chellappan, D.K.; Liew, Y.K. Characterisation of Bacterial Isolates from Infected Post-Operative Patients in a Malaysian Tertiary Heart Care Centre. Int. J. Environ. Res. Public Health 2021, 18, 9828. https://doi.org/10.3390/ ijerph18189828

Academic Editor: Paul B. Tchounwou

Received: 17 August 2021

Accepted: 8 September 2021

Published: 17 September 2021

Publisher's Note: MDPI stays neutral with regard to jurisdictional claims in published maps and institutional affiliations.

Copyright: (c) 2021 by the authors. Licensee MDPI, Basel, Switzerland. This article is an open access article distributed under the terms and conditions of the Creative Commons Attribution (CC BY) license (https:/ / creativecommons.org/licenses/by/ $4.0 /)$.

\begin{abstract}
Several bacterial species cause post-operative infections, which has been a critical health concern among hospital patients. Our study in this direction is a much-needed exploratory study that was carried out at the National Heart Institute (IJN) of Malaysia to examine the virulence properties of causative bacteria obtained from postoperative patients. The bacterial isolates and data were provided by the IJN. Antibiotic resistance gene patterns, and the ability to form biofilm were investigated for 127 isolates. Klebsiella pneumoniae (36.2\%) was the most common isolate collected, which was followed by Pseudomonas aeruginosa (26\%), Staphylococcus aureus (23.6\%), Streptococcus spp. $(8.7 \%)$ and Acinetobacter baumannii (5.5\%). There were 49 isolates that showed the presence of multidrug resistance genes. The $m e c A$ gene was surprisingly found in methicillin-susceptible $S$. aureus (MSSA), which also carried the ermA gene from those erythromycin-susceptible strains. The phenotypic antibiotic resistance profiles varied greatly between isolates. Findings from the biofilm assay revealed that 44 of the 127 isolates demonstrated the ability to produce biofilms. Our findings provide insights into the possibility of some of these bacteria surviving under antibiotic stress, and some antibiotic resistance genes being silenced.
\end{abstract}

Keywords: postoperative patients; bacterial infection; ESBL genes

\section{Introduction}

Post-operative infections constitute a major problem among post-surgical patients, and they are one of the most frequently reported healthcare-associated infections all over the world. More than $30 \%$ of health-acquired infections are post-operative infections [1]. Most of the infections are usually caused by endogenous infections, which are derived from microorganisms that are already present in the patient's body [2,3]. It is well-known that distinct microbiota compositions are observed in different skin sites in humans [4,5]. However, the causative agents may also originate from exogenous factors such as unclean operating rooms and infected surgical instruments [3]. Unsurprisingly the isolated causative agents (either endogenous or exogenous microorganisms) were mostly reported with bacteria, such as Staphylococcus aureus, Klebsiella pneumoniae, coagulase-negative staphylococci and Enterococcus species [6-8].

Post-operative infections after a heart surgery particularly, deep sternal site infections and mediastinitis, increases the rate of morbidity, mortality, and cost. The mediastinitis treatment requires more than 2 weeks additional hospital stay, as reported by Hollenbeak et al. [9]. The proportion of cardiovascular patients at high risk for post-operative infection 
is increasing due to a growing number of elderly patients who undergo cardiac surgery re-operation. Staphylococci is the predominant pathogen among Gram-positive bacteria isolated in patients with infection at the venous graft harvesting sites after a coronary artery bypass graft and also in patients with mediastinitis [10]. These pathogens play an important role in intraoperative wound contamination by infecting the sternotomy wounds during the long time intervals in open-heart surgery. Consequently, meticulous care and excessive medical supplies such as local blood supply, nutrition, and immunological support services are needed.

As might be expected, the severity of postoperative infections is always associated with prolonged use of invasive medical devices, as well as the long-term hospitalisations in intensive care units (ICU) and hospital wards [11]. In addition, the prolonged use and administration of antibiotics with inappropriate dosing have also resulted in developing resistance towards drugs [12-14]. Several studies conducted in certain countries have found the issue of improper use of antibiotics, which is prevalent among healthcare institutions [15-17]. All these factors could potentially contribute to the emergence of resistant bacterial strains. The problem of bacterial resistance towards multiple drugs was detected from the clinical isolates, where it comes to the paradigm of intraspecies or interspecies dissemination of antibiotic resistance genes. According to the Centers for Disease Control (CDC), a multidrug-resistant organism is defined as a microorganism that is resistant to one or more classes of antimicrobial agents [18]. Noordin et al. collected 318 MRSA isolates from various hospitals in Malaysia and reported that a number of strains from the total isolates were resistant to gentamicin, ciprofloxacin and erythromycin [19]. Moreover, in another study from Malaysia, researchers revealed the emergence of Gramnegative bacterial isolates that were resistant to multiple classes of antibiotics. For instance, Acinetobacter baumannii strains that were observed in a tertiary-care centre in Terengganu (Malaysia), were resistant to more than three types of antibiotic classes and a total of $72.2 \%$ were multidrug-resistant. A study conducted by Low et al., found that 39 isolates of $K$. pneumoniae were classified as multidrug-resistant and most of them showed high resistance towards polymyxin $[20,21]$. Furthermore, a study conducted in Malaysia showed that three multidrug-resistant strains of Pseudomonas aeruginosa possessing MBL genes $\left(b l a_{\mathrm{IMP}}, b l a_{\mathrm{VIM}}\right.$ and $b l a_{\mathrm{NDM}}$ ) showed multidrug resistance to carbapenem, aminoglycosides, cephalosporin, fluoroquinolone and $\beta$ - lactamase inhibitor (ticarcillin-clavulanic acid) [22].

Biofilm-producing isolates have been a challenging problem in post-operative infections. During hospitalization, patients are exposed to a pathogen-rich environment, thereby increasing the risk of infections. Healthcare workers should raise more awareness on biofilm-producing isolates to minimise the risk of postoperative infections. This is crucial because biofilm-producing strains of bacteria are more problematic than nonbiofilm-producing bacteria, due to the ability of the former to secrete extracellular polymeric substances (EPSs) [23]. These EPSs could protect the bacteria by enabling them to resist the attack of antibiotics and host defences [24]. There are several notable reports where the findings have demonstrated that biofilm producers may increase their resistance towards routine surgical preparation protocols such as skin preparation and antisepsis procedures [25-27]. In a study conducted by Howard et al., biofilm producer strains of A. baumannii were identified as a threat to cause postoperative infections due to their ability to become an opportunistic nosocomial pathogen [28]. Additionally, there were several studies indicating that the majority of the bacteria in biofilms were detected from the genera of Staphylococcus and Acinetobacter and they were considered as the most common biofilm producers [29-31]. A number of studies conducted in Malaysian hospitals also identified that biofilm-forming bacteria were associated with several problems during the treatment of extremely drug-resistant $P$. aeruginosa infections [32-34]. Consequently, the increased resistance of biofilm-associated bacterial strains towards cephalosporins and carbapenem could lead physicians to depend on colistin. This drug has been the last-resort antibiotic, which was widely used previously but discontinued in the 1980s as it caused kidney and neurological problems $[35,36]$. Vuotto et al. also found that the biofilm-forming 
K. pneumoniae strains isolated from medical devices had developed resistance towards amikacin, ciprofloxacin and piperacillin [37].

Despite having numerous investigators who have studied a range of bacterial isolates collected from different healthcare settings in Malaysia, the availability of general data on the characteristics of causative agents with regard to cardiovascular diseases is still meagre. To address these gaps, this study was conducted to explore the characteristics of $S$. aureus, K. pneumoniae, A. baumannii, P. aeruginosa and Streptococcus spp. that were isolated from the National Referral Centre for Cardiovascular Disease. The study primarily was focused on profiling the phenotypic and genotypic antimicrobial resistance in such pathogens. Moreover, we further examined the ability of these organisms to form biofilms. The findings from this study may help understand the resistance traits of the above-mentioned bacteria in greater detail. This may further assist in strategizing the postoperative infectious disease management plan for biofilm-related infections and multiple drug resistant bacterial isolates.

\section{Materials and Methods}

\subsection{Bacterial Strains}

A total of 30 S. aureus, 46 K. pneumoniae, 7 A. baumannii, 33 P. aeruginosa and 11 Streptococcus isolates were kindly provided by the National Heart Institute (IJN) of Malaysia at Kuala Lumpur. These bacterial strains were sampled from blood, wound and respiratory specimens of postoperative patients with cardiovascular diseases. All the pure bacterial cultures were stored at $-70{ }^{\circ} \mathrm{C}$ in $20 \%$ glycerol after being allowed to grow at $37^{\circ} \mathrm{C}$ in brain heart infusion (BHI) broth for $24 \mathrm{~h}$.

\subsection{Ethics}

This study was approved by the respective research ethics board, and committees of IJN as each of these isolates was accompanied by patient data that included age, gender, hospital/community acquisition, and the infection source. In addition, the IJN had also provided antimicrobial susceptibility testing provisions for up to 35 antimicrobial agents. All authors ensured that every data, such as the patient profile and medical records, were strictly used only for research purposes, and strict confidentiality was maintained.

\subsection{DNA Extraction}

DNA was extracted from all the isolates with Presto $^{\mathrm{TM}}$ Mini gDNA Bacteria Kit (Geneaid Biotech Ltd., New Taipei City, Taiwan) following the manufacturer's instructions. The quantity and quality of the extracted DNA were determined by Tecan NanoQuant plate infinite F200 (Tecan Group Ltd., Männedorf, Switzerland).

\subsection{Polymerase Chain Reaction Amplification (PCR) of Resistance Genes}

PCR analyses were performed by using an exTEN 2× PCR Master Mix (Axil Scientific Pte Ltd., Singapore) with its PCR primers and programme to screen the antibiotic resistance genes, as shown in Table 1. The PCR products were separated and analysed on a $1.4 \%$ agarose gel electrophoresis that was stained with Midori Green Advance (ca. 0.8\%) (Nippon Genetics Europe, Düren, Germany). K. pneumoniae ATCC BAA-1705, K. pneumoniae M48000, S. aureus ATCC 4330, and Enterococcus faecalis ATCC 51299 were used as control strains for genotypic screening of certain antibiotic resistance genes. Clinical resistant bacterial isolates that harboured the genetic determinants of antibiotic resistance were used as positive controls if there were no reference strains that served as control. 
Table 1. PCR primers and programme specifications for the targeted genes in the respective bacteria [38-53].

\begin{tabular}{|c|c|c|c|c|c|c|c|c|}
\hline \multirow[b]{2}{*}{ Isolates } & \multirow[b]{2}{*}{ Genes } & \multirow[b]{2}{*}{ Primers $\left(5^{\prime}-3^{\prime}\right)$} & \multirow{2}{*}{$\begin{array}{l}\text { PCR Products } \\
\text { (Base Pair) }\end{array}$} & \multicolumn{5}{|c|}{ PCR Programme Specifications } \\
\hline & & & & $\begin{array}{c}\text { Initial } \\
\text { Denaturation }\end{array}$ & Denaturation & Annealing & Extension & Final Extension \\
\hline $\begin{array}{c}\text { S. aureus } \\
\text { Streptococcus spp. }\end{array}$ & ermA & $\begin{array}{l}\text { AAG CGG TAA ACC CCT CTG A; } \\
\text { TTC GCA AAT CCC TTC TCA AC }\end{array}$ & $190 \mathrm{bp}$ & $94^{\circ} \mathrm{C}, 3 \mathrm{~min}$ & 35 cycles of $94{ }^{\circ} \mathrm{C}, 30 \mathrm{~s}$ & $55^{\circ} \mathrm{C}, 45 \mathrm{~s}$ & $72{ }^{\circ} \mathrm{C}, 45 \mathrm{~s}$ & $72{ }^{\circ} \mathrm{C}, 10 \mathrm{~min}$ \\
\hline $\begin{array}{c}\text { S. aureus } \\
\text { Streptococcus spp. }\end{array}$ & ermB & $\begin{array}{l}\text { CTATCTGATTGTTGAAGAAGGATT; } \\
\text { GTTTACTCTTGGTTTAGGATGAAA }\end{array}$ & $142 \mathrm{bp}$ & $94^{\circ} \mathrm{C}, 3 \mathrm{~min}$ & 35 cycles of $94{ }^{\circ} \mathrm{C}, 30 \mathrm{~s}$ & $55^{\circ} \mathrm{C}, 45 \mathrm{~s}$ & $72{ }^{\circ} \mathrm{C}, 45 \mathrm{~s}$ & $72{ }^{\circ} \mathrm{C}, 10 \mathrm{~min}$ \\
\hline $\begin{array}{c}\text { S. aureus } \\
\text { Streptococcus spp. }\end{array}$ & erm C & $\begin{array}{l}\text { AAT CGT CAA TTC CTG CAT GT; } \\
\text { TAA TCG TGG AAT ACG GGT TTG }\end{array}$ & 299 bp & $94^{\circ} \mathrm{C}, 3 \mathrm{~min}$ & 35 cycles of $94^{\circ} \mathrm{C}, 30 \mathrm{~s}$ & $55^{\circ} \mathrm{C}, 45 \mathrm{~s}$ & $72{ }^{\circ} \mathrm{C}, 45 \mathrm{~s}$ & $72{ }^{\circ} \mathrm{C}, 10 \mathrm{~min}$ \\
\hline $\begin{array}{c}\text { S. aureus } \\
\text { Streptococcus spp. }\end{array}$ & tetK & $\begin{array}{l}\text { GTA GCG ACA ATA GGT AAT AGT; } \\
\text { GTA GTG ACA ATA AAC CTC CTA }\end{array}$ & $360 \mathrm{bp}$ & $94^{\circ} \mathrm{C}, 3 \mathrm{~min}$ & 35 cycles of $94^{\circ} \mathrm{C}, 30 \mathrm{~s}$ & $55^{\circ} \mathrm{C}, 45 \mathrm{~s}$ & $72{ }^{\circ} \mathrm{C}, 45 \mathrm{~s}$ & $72{ }^{\circ} \mathrm{C}, 10 \mathrm{~min}$ \\
\hline $\begin{array}{c}\text { S. aureus } \\
\text { Streptococcus spp. }\end{array}$ & tet $M$ & $\begin{array}{l}\text { AGT GGA GCG ATT ACA GAA; } \\
\text { CAT ATG TCC TGG CGT GTC TA }\end{array}$ & $158 \mathrm{bp}$ & $94^{\circ} \mathrm{C}, 3 \mathrm{~min}$ & 35 cycles of $94^{\circ} \mathrm{C}, 30 \mathrm{~s}$ & $55^{\circ} \mathrm{C}, 45 \mathrm{~s}$ & $72{ }^{\circ} \mathrm{C}, 45 \mathrm{~s}$ & $72{ }^{\circ} \mathrm{C}, 10 \mathrm{~min}$ \\
\hline $\begin{array}{c}\text { S. aureus } \\
\text { Streptococcus spp. }\end{array}$ & $m s r A$ & $\begin{array}{l}\text { GAA GCA CTT GAG CGT TCT; } \\
\text { CCT TGT ATC GTG TGA TGT }\end{array}$ & $287 \mathrm{bp}$ & $95^{\circ} \mathrm{C}, 2 \mathrm{~min}$ & 30 cycles of $94{ }^{\circ} \mathrm{C}, 30 \mathrm{~s}$ & $50{ }^{\circ} \mathrm{C}, 30 \mathrm{~s}$ & $72{ }^{\circ} \mathrm{C}, 30 \mathrm{~s}$ & $72{ }^{\circ} \mathrm{C}, 4 \mathrm{~min}$ \\
\hline $\begin{array}{c}\text { S. aureus } \\
\text { Streptococcus spp. } \\
\text { K. pneumoniae } \\
\text { A. baumannii } \\
\text { P. aeruginosa }\end{array}$ & $m c r-1$ & $\begin{array}{l}\text { CGGTCAGTCCGTTTGTTC; } \\
\text { CTTGGTCGGTCTGTAGGG }\end{array}$ & $309 \mathrm{bp}$ & $94^{\circ} \mathrm{C}, 15 \mathrm{~min}$ & 25 cycles of $94^{\circ} \mathrm{C}, 30 \mathrm{~s}$ & $58^{\circ} \mathrm{C}, 90 \mathrm{~s}$ & $72{ }^{\circ} \mathrm{C}, 1 \mathrm{~min}$ & $72{ }^{\circ} \mathrm{C}, 10 \mathrm{~min}$ \\
\hline S. aureus & aacA-aphD & $\begin{array}{l}\text { TAA TCC AAG AGC AAT AAG GGC; } \\
\text { GCC ACA CTA TCA TAA CCA CTA }\end{array}$ & $227 \mathrm{bp}$ & $94^{\circ} \mathrm{C}, 3 \mathrm{~min}$ & 35 cycles of $94^{\circ} \mathrm{C}, 30 \mathrm{~s}$ & $55^{\circ} \mathrm{C}, 45 \mathrm{~s}$ & $72{ }^{\circ} \mathrm{C}, 45 \mathrm{~s}$ & $72^{\circ} \mathrm{C}, 10 \mathrm{~min}$ \\
\hline S. aureus & $\operatorname{mec} A$ & $\begin{array}{l}\text { AAAATCGATGGTAAAGGTTGGC; } \\
\text { AGTTCTGCAGTACCGGAT TTGC }\end{array}$ & $533 \mathrm{bp}$ & $95^{\circ} \mathrm{C}, 1 \mathrm{~min}$ & $\begin{array}{l}35 \text { cycles of } 95^{\circ} \mathrm{C}, 1 \\
\min \end{array}$ & $54^{\circ} \mathrm{C}, 1 \mathrm{~min}$ & $72{ }^{\circ} \mathrm{C}, 1 \mathrm{~min}$ & $72{ }^{\circ} \mathrm{C}, 5 \mathrm{~min}$ \\
\hline S. aureus & van $A$ & $\begin{array}{l}\text { GGGAAAACGACAATTGC; } \\
\text { GTACAATGCGGCCGTTA }\end{array}$ & $732 \mathrm{bp}$ & $94^{\circ} \mathrm{C}, 2 \mathrm{~min}$ & $\begin{array}{l}30 \text { cycles of } 94^{\circ} \mathrm{C}, 1 \\
\min \end{array}$ & $54^{\circ} \mathrm{C}, 1 \mathrm{~min}$ & $72{ }^{\circ} \mathrm{C}, 1 \mathrm{~min}$ & $72{ }^{\circ} \mathrm{C}, 10 \mathrm{~min}$ \\
\hline S. aureus & $\operatorname{van} B$ & $\begin{array}{l}\text { ATGGGAAGCCGATAGTC; } \\
\text { GATTTCGTTCCTCGACC }\end{array}$ & $635 \mathrm{bp}$ & $94^{\circ} \mathrm{C}, 2 \mathrm{~min}$ & $\begin{array}{l}30 \text { cycles of } 94^{\circ} \mathrm{C}, 1 \\
\min \end{array}$ & $54^{\circ} \mathrm{C}, 1 \mathrm{~min}$ & $72{ }^{\circ} \mathrm{C}, 1 \mathrm{~min}$ & $72{ }^{\circ} \mathrm{C}, 10 \mathrm{~min}$ \\
\hline $\begin{array}{c}\text { S. aureus } \\
\text { Streptococcus spp. }\end{array}$ & $\operatorname{mef}(A)$ & $\begin{array}{l}\text { AGT ATC ATT AAT CAC TAG TGC; } \\
\text { TTC TTC TGG TAC AAA AGT GG }\end{array}$ & $348 \mathrm{bp}$ & $95^{\circ} \mathrm{C}, 5 \mathrm{~min}$ & 35 cycles of $95^{\circ} \mathrm{C}, 30 \mathrm{~s}$ & $54^{\circ} \mathrm{C}, 30 \mathrm{~s}$ & $72{ }^{\circ} \mathrm{C}, 1 \mathrm{~min}$ & $72{ }^{\circ} \mathrm{C}, 5 \mathrm{~min}$ \\
\hline
\end{tabular}


Table 1. Cont.

\begin{tabular}{|c|c|c|c|c|c|c|c|c|}
\hline \multirow[b]{2}{*}{ Isolates } & \multirow[b]{2}{*}{ Genes } & \multirow[b]{2}{*}{ Primers $\left(5^{\prime}-3^{\prime}\right)$} & \multirow{2}{*}{$\begin{array}{l}\text { PCR Products } \\
\text { (Base Pair) }\end{array}$} & \multicolumn{5}{|c|}{ PCR Programme Specifications } \\
\hline & & & & $\begin{array}{c}\text { Initial } \\
\text { Denaturation }\end{array}$ & Denaturation & Annealing & Extension & Final Extension \\
\hline $\begin{array}{c}\text { S. aureus } \\
\text { Streptococcus spp. }\end{array}$ & $\operatorname{mef}(E)$ & $\begin{array}{l}\text { AGT ATC ATT AAT CAC TAG TGC; } \\
\text { TTC TTC TGG TAC AAA AGT GG }\end{array}$ & $1218 \mathrm{bp}$ & $94^{\circ} \mathrm{C}, 5 \mathrm{~min}$ & 35 cycles of $94^{\circ} \mathrm{C}, 30 \mathrm{~s}$ & $50{ }^{\circ} \mathrm{C}, 30 \mathrm{~s}$ & $72{ }^{\circ} \mathrm{C}, 90 \mathrm{~s}$ & $72^{\circ} \mathrm{C}, 5 \mathrm{~min}$ \\
\hline $\begin{array}{c}\text { A. baumannii } \\
\text { Streptococcus spp. }\end{array}$ & $p m r A$ & $\begin{array}{l}\text { TCCAGTATGGGCTTTTCCAG; } \\
\text { CCAATCCAAAGAGGAAACGA }\end{array}$ & $178 \mathrm{bp}$ & $95^{\circ} \mathrm{C}, 9 \mathrm{~min}$ & 40 cycles of $95^{\circ} \mathrm{C}, 15 \mathrm{~s}$ & $53.7^{\circ} \mathrm{C}, 1 \mathrm{~min}$ & $72^{\circ} \mathrm{C}, 1 \mathrm{~min}$ & $72^{\circ} \mathrm{C}, 5 \mathrm{~min}$ \\
\hline Streptococcus spp. & catQ & $\begin{array}{l}\text { TAGAAAGCCATACTTTGAGC; } \\
\text { CATGATGCACCTGTACAGAC }\end{array}$ & $536 \mathrm{bp}$ & $95^{\circ} \mathrm{C}, 2 \mathrm{~min}$ & 35 cycles of $95^{\circ} \mathrm{C}, 30 \mathrm{~s}$ & $50{ }^{\circ} \mathrm{C}, 30 \mathrm{~s}$ & $72{ }^{\circ} \mathrm{C}, 30 \mathrm{~s}$ & $72^{\circ} \mathrm{C}, 5 \mathrm{~min}$ \\
\hline Streptococcus spp. & $\operatorname{InuB}$ & $\begin{array}{l}\text { CCTACCTATTGTTTGTGGAA; } \\
\text { ATAACGTTACTCTCCTATTC }\end{array}$ & $944 \mathrm{bp}$ & $94^{\circ} \mathrm{C}, 5 \mathrm{~min}$ & 35 cycles of $94{ }^{\circ} \mathrm{C}, 45 \mathrm{~s}$ & $54{ }^{\circ} \mathrm{C}, 45 \mathrm{~s}$ & $72{ }^{\circ} \mathrm{C}, 1 \mathrm{~min}$ & $72^{\circ} \mathrm{C}, 5 \mathrm{~min}$ \\
\hline $\begin{array}{l}\text { K. pneumoniae } \\
\text { A. baumannii }\end{array}$ & $b l a_{\mathrm{CTX}-\mathrm{M}}$ & $\begin{array}{l}\text { TTTGCGATGTGCAGTACCAGTAA; } \\
\text { CGATATCGTTGGTGGTGCCATA }\end{array}$ & $544 \mathrm{bp}$ & $95^{\circ} \mathrm{C}, 5 \mathrm{~min}$ & 35 cycles of $95^{\circ} \mathrm{C}, 30 \mathrm{~s}$ & $51^{\circ} \mathrm{C}, 45 \mathrm{~s}$ & $72^{\circ} \mathrm{C}, 1 \mathrm{~min}$ & $72{ }^{\circ} \mathrm{C}, 10 \mathrm{~min}$ \\
\hline $\begin{array}{l}\text { K. pneumoniae } \\
\text { A. baumannii }\end{array}$ & $b l a_{\mathrm{SHV}}$ & $\begin{array}{l}\text { ATGCGTTATATTCGCCTGTG; } \\
\text { TGCTTTGTTATTCGGGCCAA }\end{array}$ & $753 \mathrm{bp}$ & $95^{\circ} \mathrm{C}, 5 \mathrm{~min}$ & 35 cycles of $95^{\circ} \mathrm{C}, 30 \mathrm{~s}$ & $60{ }^{\circ} \mathrm{C}, 45 \mathrm{~s}$ & $72{ }^{\circ} \mathrm{C}, 1 \mathrm{~min}$ & $72{ }^{\circ} \mathrm{C}, 10 \mathrm{~min}$ \\
\hline $\begin{array}{l}\text { K. pneumoniae } \\
\text { A. baumannii }\end{array}$ & $b l a_{\mathrm{KPC}-2}$ & $\begin{array}{c}\text { GTATCGCCGTCTAGTTCTG; } \\
\text { CCTTGAATGAGCTGCACAGTGG }\end{array}$ & $209 \mathrm{bp}$ & $95^{\circ} \mathrm{C}, 3 \mathrm{~min}$ & 40 cycles of $95^{\circ} \mathrm{C}, 5 \mathrm{~s}$ & $50{ }^{\circ} \mathrm{C}, 30 \mathrm{~s}$ & $72^{\circ} \mathrm{C}, 1 \mathrm{~min}$ & $72^{\circ} \mathrm{C}, 5 \mathrm{~min}$ \\
\hline $\begin{array}{l}\text { K. pneumoniae } \\
\text { A. baumannii }\end{array}$ & $b l a_{\mathrm{GES}}$ & $\begin{array}{l}\text { GTTTTGCAATGTGCTCAACG; } \\
\text { TGCCATAGCAATAGGCGTAG }\end{array}$ & $371 \mathrm{bp}$ & $95^{\circ} \mathrm{C}, 5 \mathrm{~min}$ & 35 cycles of $95^{\circ} \mathrm{C}, 30 \mathrm{~s}$ & $53{ }^{\circ} \mathrm{C}, 45 \mathrm{~s}$ & $72^{\circ} \mathrm{C}, 1 \mathrm{~min}$ & $72^{\circ} \mathrm{C}, 10 \mathrm{~min}$ \\
\hline $\begin{array}{l}\text { K. pneumoniae } \\
\text { A. baumannii }\end{array}$ & $b l a_{\mathrm{IMP}}$ & $\begin{array}{c}\text { GTTTATGTTCATACATCG; } \\
\text { GGTTTAACAAAACAACCAC }\end{array}$ & $440 \mathrm{bp}$ & $95^{\circ} \mathrm{C}, 5 \mathrm{~min}$ & 35 cycles of $95^{\circ} \mathrm{C}, 30 \mathrm{~s}$ & $45^{\circ} \mathrm{C}, 45 \mathrm{~s}$ & $72^{\circ} \mathrm{C}, 1 \mathrm{~min}$ & $72{ }^{\circ} \mathrm{C}, 10 \mathrm{~min}$ \\
\hline $\begin{array}{l}\text { K. pneumoniae } \\
\text { A. baumannii }\end{array}$ & $b l a_{\mathrm{SPM}-1}$ & $\begin{array}{l}\text { CCTACAATCTAACGGCGACC; } \\
\text { TCGCCGTGTCCAGGTATAAC }\end{array}$ & $674 \mathrm{bp}$ & $95^{\circ} \mathrm{C}, 5 \mathrm{~min}$ & $\begin{array}{l}30 \text { cycles of } 95^{\circ} \mathrm{C}, 1 \\
\min \end{array}$ & $40^{\circ} \mathrm{C}, 1 \mathrm{~min}$ & $68^{\circ} \mathrm{C}, 1 \mathrm{~min}$ & $68^{\circ} \mathrm{C}, 5 \mathrm{~min}$ \\
\hline $\begin{array}{l}\text { K. pneumoniae } \\
\text { A. baumannii }\end{array}$ & $b l a_{\mathrm{NDM}-1}$ & $\begin{array}{l}\text { GGGCAGTCGCTTCCAACGGT; } \\
\text { GTAGTGCTCAGTGTCGGCAT }\end{array}$ & 475 bp & $94^{\circ} \mathrm{C}, 3 \mathrm{~min}$ & 40 cycles of $94 \mathrm{v}, 30 \mathrm{~s}$ & $60^{\circ} \mathrm{C}, 30 \mathrm{~s}$ & $72{ }^{\circ} \mathrm{C}, 30 \mathrm{~s}$ & $72{ }^{\circ} \mathrm{C}, 3 \mathrm{~min}$ \\
\hline $\begin{array}{l}\text { K. pneumoniae } \\
\text { A. baumannii }\end{array}$ & $b l a_{\mathrm{OXA}-23}$ & $\begin{array}{l}\text { CCCCGAGTCAGATTGTTCAAGG; } \\
\text { TAC GTCGCGCAAGTTCCTGA }\end{array}$ & $330 \mathrm{bp}$ & $95^{\circ} \mathrm{C}, 15 \mathrm{~min}$ & 30 cycles of $94^{\circ} \mathrm{C}, 30 \mathrm{~s}$ & $57^{\circ} \mathrm{C}, 90 \mathrm{~s}$ & $72{ }^{\circ} \mathrm{C}, 90 \mathrm{~s}$ & $72^{\circ} \mathrm{C}, 10 \mathrm{~min}$ \\
\hline $\begin{array}{l}\text { K. pneumoniae } \\
\text { A. baumannii }\end{array}$ & $b l a_{\mathrm{OXA}-24}$ & $\begin{array}{l}\text { CACCTATGGTAATGCTCTTGC; } \\
\text { CAACCTACCTGTGGAGTAACAC }\end{array}$ & $501 \mathrm{bp}$ & $95^{\circ} \mathrm{C}, 3 \mathrm{~min}$ & 40 cycles of $95^{\circ} \mathrm{C}, 5 \mathrm{~s}$ & $50{ }^{\circ} \mathrm{C}, 30 \mathrm{~s}$ & $72^{\circ} \mathrm{C}, 1 \mathrm{~min}$ & $72^{\circ} \mathrm{C}, 5 \mathrm{~min}$ \\
\hline $\begin{array}{l}\text { K. pneumoniae } \\
\text { A. baumannii }\end{array}$ & $b l a_{\mathrm{OXA}-58}$ & $\begin{array}{l}\text { GGGGCTTGTGCTGAGCATAGT; } \\
\text { CCACTTGCCATCTGCCTTT }\end{array}$ & $688 \mathrm{bp}$ & $95^{\circ} \mathrm{C}, 15 \mathrm{~min}$ & 30 cycles of $94^{\circ} \mathrm{C}, 30 \mathrm{~s}$ & $57^{\circ} \mathrm{C}, 90 \mathrm{~s}$ & $72{ }^{\circ} \mathrm{C}, 90 \mathrm{~s}$ & $72{ }^{\circ} \mathrm{C}, 10 \mathrm{~min}$ \\
\hline
\end{tabular}




\subsection{Biofilm Formation Assay}

The ability of all the 127 bacterial isolates to form biofilms was evaluated by the method described by Stepanović et al. [53]. The method essentially utilized crystal violet to identify those bacteria, which attached firmly onto the polystyrene surface of a 96-well flat-bottomed microplate. Briefly, the overnight-maintained bacterial culture was diluted with TBS, which contained $1 \%$ glucose with a factor of 1:100. All the diluted suspensions $(200 \mu \mathrm{L})$ were incubated in a 96-well microplate for $24 \mathrm{~h}$ at $37^{\circ} \mathrm{C}$ without shaking. After that, the contents of each well were washed 3 times with water under vigorous shaking. The adherent bacteria were fixed with $200 \mu \mathrm{L}$ of $99 \%$ methanol for $15 \mathrm{~min}$. Subsequently, the microplates were emptied and were left to dry. The adherent bacteria in each well were then stained with $0.2 \mathrm{~mL}$ of crystal violet (2\%) for $5 \mathrm{~min}$ followed by rinsing with water prior to air-drying. After that, $160 \mu \mathrm{L}$ of $33 \%$ glacial acetic acid was added into each well to solubilize the adherent bacteria. The $\mathrm{OD}_{570}$ of each well was determined by a Spectramax M3 spectrophotometer (Molecular Devices, USA). S. aureus ATCC 43300 was used as a positive control, whereas negative control wells contained the TBS medium only. The cut-off $\mathrm{OD}\left(\mathrm{OD}_{\mathrm{C}}\right)$ was expressed as 3 standard deviations above the mean $\mathrm{OD}_{570}$ of the negative control. The biofilm producers were categorized as below:

$$
\begin{array}{cc}
\mathrm{OD} \leq \mathrm{ODC} & \text { non-adherent } \\
\mathrm{OD}_{\mathrm{C}}<\mathrm{OD} \leq 2 \times \mathrm{OD}_{\mathrm{C}} & \text { weakly adherent } \\
2 \times \mathrm{OD}_{\mathrm{C}}<\mathrm{OD} \leq 4 \times \mathrm{OD}_{\mathrm{C}} & \text { moderately adherent } \\
4 \times \mathrm{OD}_{\mathrm{C}}<\mathrm{OD} & \text { strongly adherent }
\end{array}
$$

\section{Results}

\subsection{Clinical Samples Detail}

All the isolates were collected from postoperative infected patients $(69.3 \%$ males and $30.7 \%$ females) in clinical wards of the IJN between March 2019 and June 2019. The average ages of patients were between 61 and 70 years (range of 1-88 years). Overall, 41 of the total 127 bacterial isolates contained Gram-positive bacteria, and the remaining contained Gram-negative organisms. Few isolates contained Gram-positive bacteria such as Streptococcus species, which were frequently identified as S. dysgalactiae subspecies equisimillis (SDSE) and S. agalactiae. Majority of the isolates were found to have originated from blood specimens $(60.0 \%)$ followed by tracheal aspirates $21.3 \%$; pus/wounds, $17.3 \%$; tissue, $2.4 \%$; bronchial, $1.6 \%$; urine, $0.79 \%$ and sputum, $0.79 \%$ as shown in Table 2 . Notably, it was observed that the isolated P. aeruginosa were mostly from respiratory tract samples compared to wounds. There were $70 \%$ of the respiratory tract samples identified as $P$. aeruginosa.

Table 2. Distribution of isolated bacteria across various infected body sites.

\begin{tabular}{cccccccc}
\hline & Blood & Pus/Wound & Tracheal & Tissue & Bronchial & Urine & Sputum \\
\hline S. aureus & 18 & 9 & 2 & 1 & 0 & 0 & 0 \\
K. pneumoniae & 35 & 5 & 4 & 0 & 1 & 0 & 1 \\
A. baumannii & 5 & 0 & 1 & 0 & 0 & 1 & 0 \\
P. aeruginosa & 2 & 8 & 20 & 2 & 1 & 0 & 0 \\
Streptococcus spp. & 11 & 0 & 0 & 0 & 0 & 0 & 0 \\
\hline
\end{tabular}

\subsection{Antibiotic Resistance Characteristics of Clinical Isolates}

According to the resistance genotype, it was interesting to note that $47.3 \%$ of MSSA strains, which supposedly do not harbour the mecA gene, were found to co-carry the antibiotic resistance genes, $m e c A$ and $\operatorname{erm} A$. Meanwhile, there was no $\mathrm{erm} B$ gene detected 
in MSSA. In this study, both erm C and tetM genes were also detected in the MSSA, and there were $68.4 \%$ of MSSA carrying the aacA-aphD gene. Unsurprisingly, the mecA gene was detected in all MRSA isolates and these isolates were resistant to oxacillin, which also co-carried erm C genes, tet $M$, as well as aacA-aphD (36.4\%). None of the $S$. aureus strains were detected with $m c r-1, \operatorname{mef}(A), \operatorname{mef}(E), m s r A$, tet $K$, van $A$ and $\operatorname{van} B$ genes. In contrast, there was one isolate of $K$. pneumoniae, which was found to carry the $m c r-1$ gene among all the isolated bacteria. The co-carriage of bla $a_{\mathrm{CTX}-\mathrm{M}}$ and $b l_{\mathrm{SHV}}$ genes was also detected in all K. pneumoniae isolates but with the absence of $b l a_{\mathrm{KPC}-2}, b l a_{\mathrm{IMP}}, b l a_{\mathrm{SPM}-1}, b l a_{\mathrm{OXA}-24}$ genes.

As listed in Table 3 and Table S1, 28.6\% of A. baumannii isolates harbored the pmrA and $b l a_{\mathrm{GES}}$ genes, respectively, while six of the seven A. baumannii isolates carried the bla $a_{\mathrm{SHV}}$ gene. The presence of the $p m r A$ genes was rare in these clinical isolates. Similarly, the $m c r-1, b l a_{\mathrm{SPM}-1}, b l a_{\mathrm{OXA}-24}$ and $b l a_{\mathrm{OXA}-58}$ genes were not detected in any of the seven isolates of A. baumannii. Among the ESBL genes, $b_{\text {CTX-M }}$ was detected in all the P. aeruginosa isolates and the $b l a_{\mathrm{SHV}}$ gene was found in $93.9 \%$ of the isolates. Surprisingly, more than half of $P$. aeruginosa isolates showed the presence of the bla $a_{\mathrm{OXA}-23}$ gene. All the P. aeruginosa isolates were $b l a_{\mathrm{OXA}-24}$ and $b l a_{\mathrm{OXA}-58}$ negative. Similarly, both the $b l a_{\mathrm{OXA}-24}$ and $b l a_{\mathrm{OXA}-58}$ genes were not detected in A. baumannii isolates as well. However, a low prevalence of the bla $a_{\text {OXA-58 }}$ gene was observed in $6.5 \%$ of K. pneumoniae isolates. It was observed that $45.5 \%$ of Streptococcus spp. isolates carried the ermB gene but not ermA and erm C genes. Both the tetK and $m e f(A)$ genes were detected in several Streptococcus species (see Supplementary Table S1). In addition, the presence of tet $M$ gene was presumptively found in $81.8 \%$ of Streptococcus spp. and 8 out of 11 of them carried the pmrA gene.

Table 3. Antibiotic resistance genes detected in clinical isolates.

\begin{tabular}{|c|c|c|c|c|c|}
\hline & S. Aureus & К. Pneumoniae & A. Baumannii & P. Aeruginosa & Streptococcus spp. \\
\hline & $(n=30)$ & $(n=46)$ & $(n=7)$ & $(n=33)$ & $(n=11)$ \\
\hline & Number (\%) & Number (\%) & Number (\%) & Number (\%) & Number (\%) \\
\hline ermA & $12(40)$ & - & - & - & $0(0)$ \\
\hline ermB & $1(3.3)$ & - & - & - & $5(45.5)$ \\
\hline ermC & $26(86.7)$ & - & - & - & $0(0)$ \\
\hline tetK & $0(0)$ & - & - & - & $1(9.1)$ \\
\hline tetM & $21(70)$ & - & - & - & $9(81.8)$ \\
\hline$m s r A$ & $0(0)$ & - & - & - & $0(0)$ \\
\hline$m c r-1$ & $0(0)$ & $1(2.17)$ & $0(0)$ & $0(0)$ & $0(0)$ \\
\hline$a a c A-a p h D$ & $19(63.3)$ & - & - & - & - \\
\hline mecA & $20(66.7)$ & - & - & - & - \\
\hline $\operatorname{van} A$ & $0(0)$ & - & - & - & - \\
\hline $\operatorname{vanB}$ & $0(0)$ & - & - & - & - \\
\hline $\operatorname{mef}(A)$ & $0(0)$ & - & - & - & $1(9.1)$ \\
\hline $\operatorname{mef}(E)$ & $0(0)$ & - & - & - & $0(0)$ \\
\hline pmrA & - & - & $2(28.6)$ & - & $8(72.7)$ \\
\hline cat $Q$ & - & - & - & - & $0(0)$ \\
\hline InиB & - & - & - & - & $0(0)$ \\
\hline$b l a_{\mathrm{CTX}-\mathrm{M}}$ & - & $46(100)$ & $3(42.9)$ & $33(100)$ & - \\
\hline$b a_{\mathrm{SHV}}$ & - & $46(100)$ & $6(85.7)$ & $31(93.9)$ & - \\
\hline$b l a_{\mathrm{KPC}-2}$ & - & $0(0)$ & $1(16.7)$ & $7(21.2)$ & - \\
\hline$b l a_{G E S}$ & - & $37(80.4)$ & $2(28.6)$ & $33(100)$ & - \\
\hline$b l a_{\mathrm{IMP}}$ & - & $0(0)$ & $1(16.7)$ & $0(0)$ & - \\
\hline$b l a_{\mathrm{VIM}}$ & - & $7(15.2)$ & $1(16.7)$ & $0(0)$ & - \\
\hline bla $a_{\mathrm{SPM}-1}$ & - & $0(0)$ & $0(0)$ & $2(6.1)$ & - \\
\hline$b l a_{\mathrm{NDM}-1}$ & - & $9(19.6)$ & $3(42.9)$ & $1(3.0)$ & - \\
\hline bla OXA-23 & - & $5(10.9)$ & $5(71.4)$ & $220(66.7)$ & - \\
\hline bla OXA-24 & - & $0(0)$ & $0(0)$ & $0(0)$ & - \\
\hline bla OXA-58 & - & $3(6.5)$ & $0(0)$ & $0(0)$ & - \\
\hline
\end{tabular}


In this study, the high rate of MDR was most predominant in the patient's tracheal samples with $46.9 \%$ among the MDR strains. In contrast, many non-MDR strains were originated from blood specimens with $42.3 \%$.

According to the antimicrobial susceptibility testing (AST) data, 49 out of 127 isolates demonstrated phenotypically resistant traits to at least three antibiotic classes, which are in accordance with the multidrug-resistant criteria (Supplementary Table S1). Based on the data, it was also noted that a total of 19 S. aureus isolates were identified as MSSA, and 11 isolates were recognized as MRSA (as shown in Table 4). As expected, all MRSA strains were resistant to benzylpenicillin and oxacillin. Both MSSA and MRSA strains were susceptible to quinupristin/dalfopristin, linezolid, vancomycin, tigecycline and nitrofurantoin. Among the S. aureus isolates, MRSA had higher rates of resistance towards antibiotics compared to MSSA. For other Gram-positive bacteria, such as Streptococcus species, there was no significant susceptibility data available as routine screening for antimicrobial susceptibility was unnecessary for them. Only 3 of the 11 Streptococcus isolates were subjected to AST, which showed resistance to clindamycin and tetracycline.

Table 4. Susceptible profiles of isolates to $\beta$-lactam and non- $\beta$-lactam antibiotics.

\begin{tabular}{|c|c|c|c|c|c|}
\hline Drug & S. aureus & K. pneumoniae & A. baumanni & P. aeruginosa & Streptococcus spp. \\
\hline & $(n=30)$ & $(n=46)$ & $(n=7)$ & $(n=33)$ & $(n=11)$ \\
\hline & Number (\%) & Number (\%) & Number (\%) & Number (\%) & Number (\%) \\
\hline Amikacin & - & $46(100)$ & - & $32(97)$ & - \\
\hline Tobramycin & - & $26(56.5)$ & $4(57.1)$ & $32(97)$ & - \\
\hline Gentamicin & $29(96.7)$ & - & - & - & - \\
\hline Benzylpenicillin & $5(16.7)$ & - & - & - & $3(27.3)$ \\
\hline Oxacillin & $19(63.3)$ & - & - & - & - \\
\hline Ampicillin & - & - & - & - & $3(27.3)$ \\
\hline Ampicillin/sulbactam & - & $14(30.4)$ & $4(57.1)$ & - & - \\
\hline Piperacillin/tazobactam & - & $25(54.3)$ & $4(57.1)$ & $22(66.7)$ & - \\
\hline Ertapenem & - & $43(93.5)$ & - & - & - \\
\hline Imipenem & - & $44(95.7)$ & $4(57.1)$ & $24(72.7)$ & - \\
\hline Meropenem & - & $44(95.7)$ & $4(57.1)$ & $24(72.7)$ & - \\
\hline Cefotetan & - & - & - & - & $1(9.1)$ \\
\hline Cefazolin & - & $15(32.6)$ & $0(0)$ & $0(0)$ & - \\
\hline Ceftazidime & - & $16(34.8)$ & $4(57.1)$ & $24(72.7)$ & - \\
\hline Ceftriaxone & - & $17(37.0)$ & - & - & $1(9.1)$ \\
\hline Cefepime & - & $19(41.3)$ & $4(57.1)$ & $24(72.7)$ & - \\
\hline Chloramphenicol & - & - & - & - & $1(9.1)$ \\
\hline Levofloxacin & $19(63.3)$ & $17(37.0)$ & $4(57.1)$ & $24(72.7)$ & $3(27.3)$ \\
\hline Teicoplanin & - & - & - & - & $1(9.1)$ \\
\hline Vancomycin & $30(100)$ & - & - & - & $3(27.3)$ \\
\hline Tigecycline & $30(100)$ & - & - & - & $3(27.3)$ \\
\hline Clindamycin & $21(70)$ & - & - & - & $2(18.2)$ \\
\hline Erythromycin & $20(66.7)$ & - & - & - & $1(9.1)$ \\
\hline Nitrofurantoin & $30(100)$ & 9 (19.6) & - & - & $2(18.2)$ \\
\hline Linezolid & $30(100)$ & - & - & - & $3(27.3)$ \\
\hline Ciprofloxacin & $19(63.3)$ & $17(37.0)$ & $4(57.1)$ & $26(78.8)$ & - \\
\hline Moxifloxacin & $19(63.3)$ & - & - & - & $3(27.3)$ \\
\hline Rifampicin & $29(96.7)$ & - & - & - & - \\
\hline Quinupristin/Dalfoprostin & $30(100)$ & - & - & - & $2(6.1)$ \\
\hline Trimethoprim/Sulfamethoxazole & $29(96.7)$ & $19(41.3)$ & $5(71.4)$ & - & - \\
\hline Tetracycline & $26(86)$ & - & - & - & $2(18.2)$ \\
\hline
\end{tabular}

For Gram-negative bacteria, the phenotypic resistance analysis revealed that $46(100 \%)$ of the K. pneumoniae isolates were susceptible to amikacin and 2 (4.3\%) were shown to have resistance phenotype to carbapenem (such as imipenem and meropenem). Some of the K. pneumoniae isolates (32.6\%) were susceptible for cefazolin, and it was noted that 
$37 \%$ of them had susceptibility towards levofloxacin. In contrast, more than half of the total number of isolates of $A$. baumannii and P. aeruginosa, demonstrated susceptibility to levofloxacin. P. aeruginosa isolates showed high percentages of susceptibility $(>70 \%)$ to the majority of the tested antibiotics, including imipenem, meropenem, ceftazidime, cefepime and levofloxacin as shown in Table 4 . In this present study, the rate of non-susceptibility among A. baumannii isolates was as follows: $100 \%(n=7)$ for cefazolin, $42.9 \%(n=3)$ for tobramycin, ampicillin/sulbacyam, piperacillin/tazobactam, imipenem, meropenem, ceftazidime, cefepime, ciprofloxacin and levofloxacin, and $28.6 \%(n=2)$ for trimethoprim/sulfamethoxazole. Some of the A. baumannii isolates sampled from the tracheal aspirates showed a similar antimicrobial susceptibility pattern to those from the bronchial aspirate, blood specimens and wounds (Table S1). However, two of A. baumannii isolates from bronchial aspirate and tracheal aspirate were resistant to all tested antibiotics by the IJN. It was also observed that ceftriaxone and levofloxacin only possessed intermediate effectiveness against $A$. baumannii isolates.

\subsection{Ability of Biofilm Formation}

In biofilm assays, 44 out of 127 isolates were categorized as biofilm producers. Among them, $11.3 \%$ were strong biofilm producers. Furthermore, 12 of the 44 biofilm producers showed moderate biofilm production and the remaining 27 (61.4\%) demonstrated weak biofilm production. Importantly, $31.8 \%$ of biofilm producers carried multiple antibiotic resistance genes. The percentage ability in forming biofilms among the MDR isolates was as follows: $57.1 \%$ for weak biofilm producers; $28.8 \%$ for moderate biofilm producers and $14.3 \%$ for strong biofilm producers. Interestingly, there were two strong biofilm producers identified as multidrug-resistant strains according to their phenotypic resistance profiles. Both were resistant to cefazolin, ceftazidime and cefepime. Further details of each biofilm producer are summarised in Supplementary Table S1.

\section{Discussion}

The rising incidence of microbial resistance to antibiotics has caused considerable challenges in the management of postoperative infections due to the lack of effective therapeutic options. This rise in incidence has been leading to increased morbidity and mortality rates in postoperative infections, prolonged hospital stays and consequently higher management costs. The majority of the causative agents associated with postoperative infections are the ESCAPE (Enterococcus faecium, Staphylococcus aureus, Clostridium difficille, Acinetobacter baumannii, Pseudomonas aeruginosa, and Enterobacteriaceae species) group of pathogens [54]. These organisms are capable to 'escape' antibacterial actions of the current range of antibiotics. In addition, some of them are normal flora to humans and may acquire antibiotic resistance elements via inter- or intraspecies gene transfer between them. Meanwhile, misuse of antibiotics has also caused enormous damage in aggravating antimicrobial resistance, which now seems to develop faster than usual.

Unlike previous reports [55-57], which stated that the majority of postoperative infections are caused by S. aureus, our study showed that most of the cardiac surgery patients were prone to severe postoperative infections caused by K. pneumoniae. This observation was consistent with the findings from Hope et al. [58]. Besides, another study also reported that K. pneumoniae was one of the leading isolates in postoperative infections, which accounted for $50 \%$ cases, followed by S. aureus (27.8\%) [59]. In the present study, we found that K. pneumoniae was the most predominant organism, which caused postoperative infections in $36.2 \%$ of subjects, followed by P. aeruginosa (26\%), paralleling with the study-findings reported by Ali et al. [60]. Ali et al. stated that superficial incisional surgical site infections, which were the most common type of postoperative infections in surgical patients, were predominantly caused by K. pneumoniae [60]. The virulence factor of $K$. pneumoniae might be the possible explanation for the high number of K. pneumoniae infection contributors in our study. The outer layer of K. pneumoniae inhibits phagocytosis by reducing the amount of complement component 3 (C3) that binds 
to the surface of K. pneumoniae, as demonstrated by Guadalupe et al. [61]. Therefore, most of the polymorphonuclear cells lack the killing efficacy when K. pneumoniae was not opsonised by C3. Similarly, P. aeruginosa was also shown to be able to evade the host immunity (especially in those who are immunosuppressed and are hospitalized) via its slime production, which prevents the complement components deposition that commonly leads to phagocytosis [62-64]. Therefore, P. aeruginosa was identified as the second most dominant causative bacteria isolated from our study, which was followed by $S$. aureus. It is not surprising that $S$. aureus is one of the isolates harvested from these patients because it is well-known as an opportunistic bacterium associated with bacteraemia and surgical site infection. In contrast, only 11 isolates of Streptococcus spp. were collected from cases of postoperative infection. All these streptococcal isolates were isolated from blood specimens, where $81.8 \%$ of them were beta-haemolytic streptococcus. The low number of Streptococcus spp. in our total specimens is consistent with the study conducted by Chaudhary et al. [55] in a surgical ward of Bharatour Hospital, Chitwan, Nepal, which reported only $1.5 \%$ of Streptococcus spp. as observed under surgical site infections.

In the present study, the antibiotic susceptibility data were compared with the antibiotic resistance gene patterns in S. aureus, K. pneumoniae, A. baumanni, P. aeruginosa and Streptococcus spp. isolates. To our knowledge, this is the first report of bacterial genotypic and phenotypic antibiotic resistance patterns from our local heart specialist institution IJN. The antibiotic susceptibility results showed a high resistance rate among the K. pneumoniae isolates to ampicillin/sulbactam (69.6\%), which is the highest among all the conventional antibiotics. All K. pneumoniae isolates were found to be positive to bla $a_{\mathrm{CTX}-\mathrm{M}}$ and bla $\mathrm{SHV}_{\mathrm{S}}$ as confirmed by PCR studies, unlike the report of Kiratisin et al., which stated that the

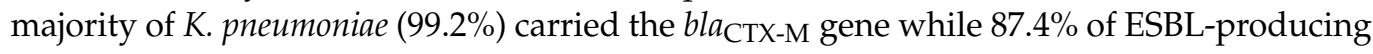
K. pneumoniae carried the bla $a_{\mathrm{SHV}}$ gene [65]. The combined presence of three ESBL genes $\left(b l a_{\mathrm{CTX}-\mathrm{M}}, b l a_{\mathrm{GES}}\right.$ and $\left.b l a_{\mathrm{SHV}}\right)$ in the same K. pneumoniae isolates were $80.4 \%$. In contrast, a low percentage of multiple ESBL genes in ESBL-producing K. pneumoniae was reported in the findings from Mohsen et al. (28\%) and Apisarnthanarak et al. (24\%) [66,67]. Although all the K. pneumoniae isolates harboured the bla $a_{\mathrm{SHV}}$ gene that was responsible for cephalosporin resistance, some of the K. pneumoniae isolates were still susceptible to cefepime $(41.3 \%)$, ceftriaxone $(37.0 \%)$, cefazolin $(32.6 \%)$ and ceftazidime $(34.8 \%)$. There was another study, which demonstrated that, the absence of cephalosporin phenotypic properties in the bla $a_{\mathrm{SHV}}$ gene-carrying $K$. pneumoniae isolates could be caused by the growth conditions and environment of the bacteria. Changes in the growth conditions may affect the bacteria's physiological adaptations, resulting in changes in its metabolic process [68]. The regulatory proteins of bacteria are always controlled by nutrient availability and its metabolites. In K. pneumoniae, some of the amino acids were found to bind to the repressors, which in turn had bound to the regulatory sites on DNA, which resulted in bla $a_{\mathrm{SHV}}$ gene suppression.

As expected, a total of $11(36.7 \%)$ S. aureus isolates were found to be methicillinresistant strains (MRSA), where all of them were resistant to benzylpenicillin and oxacillin. Interestingly, 9 of the MSSA strains, which were susceptible to oxacillin also contained the gene, which confers resistance to oxacillin, called mecA. This means some staphylococcal isolates could still be killed by oxacillin, despite the presence of mecA. Similarly, Proulx et al. revealed a similar finding where they concluded that this phenomenon may be due to genetically inactivated mecA in MSSA. This phenomenon is called silencing of antibiotic resistance by mutation (SARM). SARM results in non-functional antibiotic resistance protein as mutation is found at its genetic coding region, which affects its transcription or translation functionalities [57]. Other than the mecA gene, some of the MSSA isolates, which expressed its erythromycin susceptible phenotype, were found to harbour the ermA and erm $C$ genes. Supposedly, the erm genes encode the erythromycin-resistance methyltransferase to initiate the ribosomal RNA methylation. The methylation of ribosomal RNA will inhibit erythromycin-binding resulting in MSSA resistance to erythromycin [69]. Similar observations were reported by Zmantar et al. [70] and Sekiguchi et al. where they 
had reported the absence of the resistance phenotype towards erythromycin in isolates, in spite of the presence of erm genes [71] Sekiguchi et al. suggested that there might be a mutational event in the coding or promoter region of the erm gene, which was carried by $S$. aureus strains as evidenced via PCR analysis [71]. In addition to the ermA or ermC gene, the presence of the ermB gene was also detected in this study for S. aureus; but only $3.3 \%$, which corroborates with the findings of Eady et al. in clinical S. aureus isolates [72].

Infection with multidrug-resistant bacteria has been associated with significant morbidity and mortality. In this study, we found that the prevalence of multidrug-resistant (MDR) strains was $38.6 \%$ (49 out of 127 isolates), which is a significant proportion that can affect the treatment of patients with postoperative infections. Cefazolin showed the highest resistance rate $(81.6 \%)$ among the multidrug-resistant isolates. Another study conducted at a national hospital in an East African country depicted a much higher rate of MDR (63\%) among the pathogens that caused postoperative infections [73]. Among MDR $P$. aeruginosa, piperacillin exhibited the highest resistance pattern $(100 \%)$. Furthermore, Tavajjohi et al. also reported that $89.3 \%$ of MDR P. aeruginosa isolates in their study were resistant to piperacillin. [74] Multidrug-resistant status is one of the significant determinants of hospital mortality. Hospital-acquired infections associated with P. aeruginosa and A. baumannii were $8.4 \%$ in the study conducted by Motbainor et al. [75]. All the isolates of MDR P. aeruginosa and A. baumannii were resistant to cefazolin and six of the nine MDR $P$. aeruginosa isolates were resistant to piperacillin/tazobactam. The cefazolin resistance rate was found to be lower compared to the report from Northwest Ethiopia [75]. Most recently, a study has shown that the presence of the bla $a_{\mathrm{KPC}-2}$ gene in P. aeruginosa could be associated with its susceptibility to ceftazidime-avibactam by increasing the minimum inhibitory concentration value [76]. In the present study, $27.3 \%$ of $P$. aeruginosa were revealed to be resistant to ceftazidime. The high number of MDR among P. aeruginosa and A. baumannii observed in postoperative patients in IJN was probably related to cross-contamination of these bacteria in the hospital environment or some other unknown factors, which is not the focus of this present study.

From the 127 bacterial isolates screened for biofilm formation, 44 of them were detected to be biofilm producers. This feature may contribute to the development of antibiotic resistance and plays an important role in evading the effect of immune defense mechanism. K. pneumoniae $13(28.2 \%)$, P. aeruginosa $11(33.3 \%)$, S. aureus $9(30 \%)$, Streptococcus spp. $6(54.5 \%)$, and A. baumannii $5(71.4 \%)$ were among the leading biofilm producers as found in this study. However, the number of biofilm producers that were found in this study was not as high as in the study reported by Barsoumian et al., which reported $60.4 \%$ of biofilm producers detected in clinical samples [77]. Biofilms could be an important concern since there are studies that showed that biofilms play a key role in bacterial transmissions in different areas of a hospital. These may also include the cross-transmission of bacteria within a clinical setting or high-contact equipment items such as stethoscopes, ventilators, and phones. Healthcare workers, especially with poor hand hygiene, may be responsible for further environmental contamination as they work across different patient zones every day $[78,79]$. Besides, horizontal gene transfer, which is the process for antibiotic resistance gene interchange, frequently happens in biofilms [80]. This causes genetic variation in bacteria, consequently resulting in superbug infection-bacteria development. Several studies have revealed that the rate of horizontal gene transfer of antibiotic-resistant genes is typically higher in the biofilm community compared to those in planktonic cultures [81,82]. Hence, biofilm is believed to be the main antibiotic-resistant gene reservoir for genetic exchange among bacterial species. Nevertheless, the biofilm data in our study is nonconclusive to confirm if the detected MDR strains as aforementioned were a consequence of the presence of these biofilm producers.

\section{Conclusions}

Taken together, the findings of this present study could further guide and advance the knowledge base of existing antibiotic resistance principles and surgical procedure 
guidelines, which may, in turn, improve the quality of postoperative care for patients. Furthermore, our study also reports the high prevalence of postoperative infection cases and the emergence of MDR bacteria, which have highlighted the challenges and difficulties in the management of postoperative infections. Although the number of MDR isolates and biofilm producer rates were relatively low in this present study, prudent antimicrobial use and effective infection prevention and control (IPC) strategies are important to prevent further development of multidrug resistance and the emergence of newer biofilm-producing strains.

Supplementary Materials: The following are available online at https: / www.mdpi.com/article/ 10.3390/ijerph18189828/s1, Table S1: Degree of biofilm formation and resistance gene among the patient's specimen with the resistance pattern of bacterial isolates to 11 antibiotic classes.

Author Contributions: Y.K.L. provided the conceptualisation and supervision; Y.K.Y. was involved in investigation, writing and original draft preparation; N.C.M.W., G.E.C.Y. and Z.X.C. involved in investigation and analysis; L.L.C., N.Z.M.Z. and D.K.C. reviewed and edited the manuscript. All authors have read and agreed to the published version of the manuscript.

Funding: This research was funded by IMU undergraduate research, grant number BMSc I-2019 (01).

Institutional Review Board Statement: The study was conducted according to the guidelines of the Declaration of Helsinki, and approved by the IJN Research Ethics Committee (IJNREC/412/2019 and 24 June 2019).

Informed Consent Statement: Informed consent was obtained from all subjects involved in the study.

Data Availability Statement: The data presented in this study are available in Supplementary Table S1.

Acknowledgments: Y.K.Y. and Y.K.L. would like to thank the School of Postgraduate Studies and the Institute for Research, Development and Innovation (IRDI) of the International Medical University for the support given.

Conflicts of Interest: The authors declare no conflict of interest.

\section{References}

1. WHO. Global Guidelines on the Prevention of Surgical Site Infection; WHO: Geneva, Switzerland, 2017.

2. Haque, M.; Sartelli, M.; McKimm, J.; Bakar, M.A. Health care-associated infections-An overview. Infect. Drug Resist. 2018, 11, 2321-2333. [CrossRef]

3. Torpy, J.M.; Burke, A.E.; Glass, R.M. Postoperative infections. JAMA—J. Am. Med. Assoc. 2010, 303, 2544. [CrossRef]

4. Byrd, A.L.; Belkaid, Y.; Segre, J.A. The human skin microbiome. Nat. Rev. Microbiol. 2018, 16, 143-155. [CrossRef]

5. Shibagaki, N.; Suda, W.; Clavaud, C.; Bastien, P.; Takayasu, L.; Iioka, E.; Kurokawa, R.; Yamashita, N.; Hattori, Y.; Shindo, C.; et al. Aging-related changes in the diversity of women's skin microbiomes associated with oral bacteria. Sci. Rep. 2017, 7, 10567. [CrossRef] [PubMed]

6. Mundhada, A.; Tenpe, S. A study of organisms causing surgical site infections and their antimicrobial susceptibility in a tertiary care Government Hospital. Indian J. Pathol. Microbiol. 2015, 58, 195-200. [CrossRef] [PubMed]

7. Lin, Y.T.; Hsieh, K.S.; Chen, Y.S.; Huang, I.F.; Cheng, M.F. Infective endocarditis in children without underlying heart disease. J. Microbiol. Immunol. Infect. 2013, 46, 121-128. [CrossRef] [PubMed]

8. NNIS System. National Nosocomial Infections Surveillance (NNIS) System Report, data summary from January 1992 through June 2003, issued August 2003. Am. J. Infect. Control 2003, 31, 481-498. [CrossRef] [PubMed]

9. Hollenbeak, C.S.; Murphy, D.M.; Koenig, S.; Woodward, R.S.; Dunagan, W.C.; Fraser, V.J. The clinical and economic impact of deep chest surgical site infections following coronary artery bypass graft surgery. Chest 2000, 118, 397-402. [CrossRef] [PubMed]

10. Michalopoulos, A.; Geroulanos, S.; Rosmarakis, E.S.; Falagas, M.E. Frequency, characteristics, and predictors of microbiologically documented nosocomial infections after cardiac surgery. Eur. J. Cardio-Thorac. Surg. 2006, 29, 456-460. [CrossRef] [PubMed]

11. Markogiannakis, H.; Pachylaki, N.; Samara, E.; Kalderi, M.; Minettou, M.; Toutouza, M.; Toutouzas, K.G.; Theodorou, D.; Katsaragakis, S. Infections in a surgical intensive care unit of a university hospital in Greece. Int. J. Infect. Dis. 2009, 13, 145-153. [CrossRef] [PubMed]

12. Alavi, S.M.; Roozbeh, F.; Behmanesh, F.; Alavi, L. Antibiotics use patterns for surgical prophylaxis site infection in different surgical wards of a teaching hospital in Ahvaz, Iran. Jundishapur J. Microbiol. 2014, 7, e12251. [CrossRef] [PubMed]

13. Enzler, M.J.; Berbari, E.; Osmon, D.R. Antimicrobial prophylaxis in adults. Mayo Clin. Proc. 2011, 86, 686-701. [CrossRef] 
14. Talbot, T.R. Surgical site infections and antimicrobial prophylaxis. In Principle and Practice of Infectious Diseases, 7th ed.; Mandell, G.L., Bennett, J.E., Dolin, R., Eds.; Churchill Livingstone: Philadelphia, PA, USA, 2010.

15. Yadesa, T.M.; Gudina, E.K.; Angamo, M.T. Antimicrobial use-related problems and predictors among hospitalized medical in-patients in Southwest Ethiopia: Prospective observational study. PLoS ONE 2015, 10, e0138385. [CrossRef] [PubMed]

16. Lim, M.K.; Lai, P.S.M.; Ponnampalavanar, S.S.L.S.; Omar, S.F.S.; Taib, N.A.; Yusof, M.Y.; Italiano, C.M.; Kong, D.C.M.; Kamarulzaman, A. Antibiotics in surgical wards: Use or misuse? A newly industrialized country's perspective. J. Infect. Dev. Ctries. 2015, 9, 1264-1271. [CrossRef]

17. Abrha, S.; Assefa, R.; Molla, F.; Melkam, W.; Assen, A.; Mulugeta, A.; Wondimu, A.; Mohammed, J.; Birhanetensae, M.; Masresha, B. Antibiotics Utilization and their Cost in Ayder Referral Hospital, Mekelle, Ethiopia. Glob. J. Med. Res. 2015, 15, 1-9.

18. Background I MDRO Management I Guidelines Library I Infection Control I CDC. Available online: https://www.cdc.gov / infectioncontrol/guidelines/mdro/background.html (accessed on 31 January 2021).

19. Noordin, A.; Sapri, H.F.; Sani, N.A.M.; Leong, S.K.; Tan, X.E.; Tan, T.L.; Zin, N.M.; Neoh, H.M.; Hussin, S. Antimicrobial resistance profiling and molecular typing of methicillin-resistant Staphylococcus aureus isolated from a Malaysian teaching hospital. J. Med. Microbiol. 2016, 65, 1476-1481. [CrossRef]

20. Lean, S.S.; Suhaili, Z.; Ismail, S.; Rahman, N.I.A.; Othman, N.; Abdullah, F.H.; Jusoh, Z.; Yeo, C.C.; Thong, K.L. Prevalence and genetic characterization of carbapenem- and polymyxin-resistant Acinetobacter baumannii isolated from a tertiary hospital in Terengganu, Malaysia. ISRN Microbiol. 2014, 2014, 953417. [CrossRef]

21. Low, Y.M.; Yap, P.S.X.; Abdul Jabar, K.; Ponnampalavanar, S.; Karunakaran, R.; Velayuthan, R.; Chong, C.W.; Abu Bakar, S.; Md Yusof, M.Y.; Teh, C.S.J. The emergence of carbapenem resistant Klebsiella pneumoniae in Malaysia: Correlation between microbiological trends with host characteristics and clinical factors. Antimicrob. Resist. Infect. Control 2017, 6, 5. [CrossRef] [PubMed]

22. Liew, S.M.; Rajasekaram, G.; Puthucheary, S.D.; Chua, K.H. Detection of VIM-2-, IMP-1- and NDM-1-producing multidrugresistant Pseudomonas aeruginosa in Malaysia. J. Glob. Antimicrob. Resist. 2018, 13, 271-273. [CrossRef]

23. Nirwati, H.; Sinanjung, K.; Fahrunissa, F.; Wijaya, F.; Napitupulu, S.; Hati, V.P.; Hakim, M.S.; Meliala, A.; Aman, A.T.; Nuryastuti, T. Biofilm formation and antibiotic resistance of Klebsiella pneumoniae isolated from clinical samples in a tertiary care hospital, Klaten, Indonesia. BMC Proc. 2019, 13, 20. [CrossRef] [PubMed]

24. Chung, P.Y. The emerging problems of Klebsiella pneumoniae infections: Carbapenem resistance and biofilm formation. FEMS Microbiol. Lett. 2016, 363, fnw219. [CrossRef] [PubMed]

25. Bonez, P.C.; Dos Santos Alves, C.F.; Dalmolin, T.V.; Agertt, V.A.; Mizdal, C.R.; Flores, V.D.C.; Marques, J.B.; Santos, R.C.V.; Anraku De Campos, M.M. Chlorhexidine activity against bacterial biofilms. Am. J. Infect. Control 2013, 41, e119-e122. [CrossRef] [PubMed]

26. Knobloch, J.K.M.; Horstkotte, M.A.; Rohde, H.; Kaulfers, P.M.; Mack, D. Alcoholic ingredients in skin disinfectants increase biofilm expression of Staphylococcus epidermidis. J. Antimicrob. Chemother. 2002, 49, 683-687. [CrossRef] [PubMed]

27. Rood, K.M.; Buhimschi, I.A.; Jurcisek, J.A.; Summerfield, T.L.; Zhao, G.; Ackerman, W.E.; Wang, W.; Rumpf, R.W.; Thung, S.F.; Bakaletz, L.O.; et al. Skin microbiota in obese women at risk for surgical site infection after cesarean delivery. Sci. Rep. 2018, 8, 8756. [CrossRef]

28. Howard, A.; O’Donoghue, M.; Feeney, A.; Sleator, R.D. Acinetobacter baumannii: An emerging opportunistic pathogen. Virulence 2012, 3, 243-250. [CrossRef]

29. Choong, P.F.M.; Dowsey, M.M.; Carr, D.; Daffy, J.; Stanley, P. Risk factors associated with acute hip prosthetic joint infections and outcome of treatment with a rifampinbased regimen. Acta Orthop. 2007, 78, 755-765. [CrossRef]

30. Jämsen, E.; Huhtala, H.; Puolakka, T.; Moilanen, T. Risk factors for infection after knee arthroplasty. A register-based analysis of 43,149 cases. J. Bone Joint Surg. Am. 2009, 91, 38-47. [CrossRef]

31. Revdiwala, S.; Rajdev, B.M.; Mulla, S. Characterization of bacterial etiologic agents of biofilm formation in medical devices in critical care setup. Crit. Care Res. Pract. 2012, 2012, 945805. [CrossRef]

32. Mulcahy, L.R.; Isabella, V.M.; Lewis, K. Pseudomonas aeruginosa biofilms in disease. Microb. Ecol. 2014, 68, 1-12. [CrossRef]

33. Moradali, M.F.; Ghods, S.; Rehm, B.H.A. Pseudomonas aeruginosa lifestyle: A paradigm for adaptation, survival, and persistence. Front. Cell. Infect. Microbiol. 2017, 7, 39. [CrossRef]

34. Solomkin, J.S.; Mazuski, J.E.; Bradley, J.S.; Rodvold, K.A.; Goldstein, E.J.C.; Baron, E.J.; O'Neill, P.J.; Chow, A.W.; Patchen Dellinger, E.; Eachempati, S.R.; et al. Diagnosis and management of complicated intra-abdominal infection in adults and children: Guidelines by the surgical infection society and the infectious diseases society of america. Clin. Infect. Dis. 2010, 50, 133-164. [CrossRef]

35. Johansen, H.K.; Moskowitz, S.M.; Ciofu, O.; Pressler, T.; Høiby, N. Spread of colistin resistant non-mucoid Pseudomonas aerginosa among chronically infected Danish cystic fibrosis patients. J. Cyst. Fibros. 2008, 7, 391-397. [CrossRef] [PubMed]

36. Nation, R.L.; Li, J. Colistin in the 21st century. Curr. Opin. Infect. Dis. 2009, 22, 535-543. [CrossRef]

37. Vuotto, C.; Longo, F.; Balice, M.P.; Donelli, G.; Varaldo, P.E. Antibiotic resistance related to biofilm formation in Klebsiella pneumoniae. Pathogens 2014, 3, 743-758. [CrossRef]

38. Strommenger, B.; Kettlitz, C.; Werner, G.; Witte, W. Multiplex PCR assay for simultaneous detection of nine clinically relevant antibiotic resistance genes in Staphylococcus aureus. J. Clin. Microbiol. 2003, 41, 4089-4094. [CrossRef] [PubMed] 
39. Liu, Y.Y.; Wang, Y.; Walsh, T.R.; Yi, L.X.; Zhang, R.; Spencer, J.; Doi, Y.; Tian, G.; Dong, B.; Huang, X.; et al. Emergence of plasmid-mediated colistin resistance mechanism MCR-1 in animals and human beings in China: A microbiological and molecular biological study. Lancet Infect. Dis. 2016, 16, 161-168. [CrossRef]

40. Hujier, N.S.A. Detection of Methicillin-Resistant Staphylococcus aureus in Nosocomial Infections in Gaza Strip. Master's Thesis, The Islamic University—Gaza, Gaza, Palestine, 2006. Available online: https://library.iugaza.edu.ps/thesis/71122.pdf (accessed on 3 February 2021).

41. Dutka-Malen, S.; Evers, S.; Courvalin, P. Detection of glycopeptide resistance genotypes and identification to the species level of clinically relevant enterococci by PCR. J. Clin. Microbiol. 1995, 33, 24-27. [CrossRef] [PubMed]

42. El Ashkar, S.; Osman, M.; Rafei, R.; Mallat, H.; Achkar, M.; Dabboussi, F.; Hamze, M. Molecular detection of genes responsible for macrolide resistance among Streptococcus pneumoniae isolated in North Lebanon. J. Infect. Public Health 2017, 10, 745-748. [CrossRef]

43. Avrain, L.; Garvey, M.; Mesaros, N.; Glupczynski, Y.; Mingeot-Leclercq, M.-P.; Piddock, L.J.V.; Tulkens, P.M.; Vanhoof, R.; Van Bambeke, F. Selection of quinolone resistance in Streptococcus pneumoniae exposed in vitro to subinhibitory drug concentrations. J. Antimicrob. Chemother. 2007, 60, 965-972. [CrossRef]

44. Del Grosso, M.; Camilli, R.; Barbabella, G.; Northwood, J.B.; Farrell, D.J.; Pantosti, A. Genetic resistance elements carrying mef subclasses other than mef $(A)$ in Streptococcus pyogenes. Antimicrob. Agents Chemother. 2011, 55, 3226-3230. [CrossRef]

45. Chaffanel, F.; Charron-Bourgoin, F.; Libante, V.; Leblond-Bourget, N.; Payot, S.; Schaffner, D.W. Resistance genes and genetic elements associated with antibiotic resistance in clinical and commensal isolates of Streptococcus salivarius. Appl. Environ. Microbiol. 2015, 81, 4155-4163. [CrossRef]

46. Guo, Y.; Deng, X.; Liang, Y.; Zhang, L.; Zhao, G.P.; Zhou, Y. The draft genomes and investigation of serotype distribution, antimicrobial resistance of group B Streptococcus strains isolated from urine in Suzhou, China. Ann. Clin. Microbiol. Antimicrob. 2018, 17, 28. [CrossRef]

47. Moghadampour, M.; Rezaei, A.; Faghri, J. The emergence of bla $a_{\mathrm{OXA}-48}$ and bla $a_{\mathrm{NDM}}$ among ESBL-producing Klebsiella pneumoniae in clinical isolates of a tertiary hospital in Iran. Acta Microbiol. Immunol. Hung. 2018, 65, 335-344. [CrossRef]

48. Geyer, C.N.; Hanson, N.D. Rapid PCR amplification protocols decrease the turn-around time for detection of antibiotic resistance genes in Gram-negative pathogens. Diagn. Microbiol. Infect. Dis. 2013, 77, 113-117. [CrossRef] [PubMed]

49. Gales, A.C.; Menezes, L.C.; Silbert, S.; Sader, H.S. Dissemination in distinct Brazilian regions of an epidemic carbapenem-resistant Pseudomonas aeruginosa producing SPM metallo- $\beta$-lactamase. J. Antimicrob. Chemother. 2003, 52, 699-702. [CrossRef] [PubMed]

50. Moosavian, M.; Rahimzadeh, M. Molecular detection of metallo- $\beta$-lactamase genes, $b l a_{\mathrm{IMP}-1}, b l a_{\mathrm{VIM}-2}$ and $b l a_{\mathrm{SPM}-1}$ in imipenem resistant Pseudomonas aeruginosa isolated from clinical specimens in teaching hospitals of Ahvaz, Iran. Iran. J. Microbiol. 2015, 7, 2-6.

51. Manchanda, V.; Gupta, S.; Chopra, R.; Verma, N.; Kaur, I.; Rai, S.; Rautela, R.; Rawat, D.; Singh, N.; Bhalla, P. Development of TaqMan real-time polymerase chain reaction for the detection of the newly emerging form of carbapenem resistance gene in clinical isolates of Escherichia coli, Klebsiella pneumoniae, and Acinetobacter baumannii. Indian J. Med. Microbiol. 2011, 29, $249-253$. [CrossRef]

52. Bogaerts, P.; de Castro, R.R.; de Mendonça, R.; Huang, T.D.; Denis, O.; Glupczynski, Y. Validation of carbapenemase and extended-spectrum $\beta$-lactamase multiplex endpoint PCR assays according to ISO 15189. J. Antimicrob. Chemother. 2013, 68, 1576-1582. [CrossRef]

53. Stepanović, S.; Vuković, D.; Dakić, I.; Savić, B.; Švabić-Vlahović, M. A modified microtiter-plate test for quantification of staphylococcal biofilm formation. J. Microbiol. Methods 2000, 40, 175-179. [CrossRef]

54. Surgical Site Infections-Infectious Disease Advisor. Available online: https:/ / www.infectiousdiseaseadvisor.com/home/decisionsupport-in-medicine/hospital-infection-control/surgical-site-infections/ (accessed on 15 February 2021).

55. View of Surgical Site Infections and Antimicrobial Resistance Pattern. Available online: https://jnhrc.com.np/index.php/jnhrc/ article/view/1048/626 (accessed on 15 February 2021).

56. Pal, S.; Sayana, A.; Joshi, A.; Juyal, D. Staphylococcus aureus: A predominant cause of surgical site infections in a rural healthcare setup of Uttarakhand. J. Fam. Med. Prim. Care 2019, 8, 3600-3606.

57. Kime, L.; Randall, C.P.; Banda, F.I.; Coll, F.; Wright, J.; Richardson, J.; Empel, J.; Parkhill, J.; O’Neill, A.J. Transient silencing of antibiotic resistance by mutation represents a significant potential source of unanticipated therapeutic failure. $m$ Bio 2019, 10, e01755-19. [CrossRef]

58. Hope, D.; Ampaire, L.; Oyet, C.; Muwanguzi, E.; Twizerimana, H.; Apecu, R.O. Antimicrobial resistance in pathogenic aerobic bacteria causing surgical site infections in Mbarara regional referral hospital, Southwestern Uganda. Sci. Rep. 2019, 9, 17299. [CrossRef]

59. Lubega, A.; Joel, B.; Justina Lucy, N. Incidence and etiology of surgical site infections among emergency postoperative patients in Mbarara regional referral hospital, South Western Uganda. Surg. Res. Pract. 2017, 2017, 6365172. [CrossRef]

60. Ali, K.M.; Al-Jaff, B.M.A. Source and antibiotic susceptibility of Gram-negative bacteria causing superficial incisional surgical site infections. Int. J. Surg. Open 2021, 30, 100318. [CrossRef]

61. Cortés, G.; Borrell, N.; De Astorza, B.; Gómez, C.; Sauleda, J.; Albertí, S. Molecular analysis of the contribution of the capsular polysaccharide and the lipopolysaccharide $\mathrm{O}$ side chain to the virulence of Klebsiella pneumoniae in a murine model of pneumonia. Infect. Immun. 2002, 70, 2583-2590. [CrossRef] 
62. Neut, D.; Hendriks, J.G.E.; van Horn, J.R.; van der Mei, H.C.; Busscher, H.J. Pseudomonas aeruginosa biofilm formation and slime excretion on antibiotic-loaded bone cement. Acta Orthop. 2005, 76, 109-114. [CrossRef] [PubMed]

63. Prasad, S.V.; Ballal, M.; Shivananda, P.G. Slime production a virulence marker in Pseudomonas aeruginosa strains isolated from clinical and environmental specimens: A comparative study of two methods. Indian J. Pathol. Microbiol. 2009, 52, 191-193. [PubMed]

64. Kuang, Z.; Hao, Y.; Walling, B.E.; Jeffries, J.L.; Ohman, D.E.; Lau, G.W. Pseudomonas aeruginosa elastase provides an escape from phagocytosis by degrading the pulmonary surfactant protein-A. PLoS ONE 2011, 6, e27091. [CrossRef] [PubMed]

65. Kiratisin, P.; Apisarnthanarak, A.; Laesripa, C.; Saifon, P. Molecular characterization and epidemiology of extended-spectrum- $\beta$ lactamase-producing Escherichia coli and Klebsiella pneumoniae isolates causing health care-associated infection in Thailand, where the CTX-M family is endemic. Antimicrob. Agents Chemother. 2008, 52, 2818-2824. [CrossRef]

66. Mahdi Yahya Mohsen, S.; Hamzah, H.A.; Muhammad Imad Al-Deen, M.; Baharudin, R. Antimicrobial susceptibility of Klebsiella pneumoniae and Escherichia coli with extended-spectrum $\beta$-lactamase associated genes in hospital Tengku Ampuan Afzan, Kuantan, Pahang. Malaysian J. Med. Sci. 2016, 23, 14-20.

67. Apisarnthanarak, A.; Kiratisin, P.; Mundy, L.M. Clinical and molecular epidemiology of healthcare-associated infections due to extended-spectrum $\beta$-lactamase (ESBL)-producing strains of Escherichia coli and Klebsiella pneumoniae that harbor multiple ESBL genes. Infect. Control Hosp. Epidemiol. 2008, 29, 1026-1034. [CrossRef]

68. Microbial Growth-Biology LibreTexts. Available online: https://bio.libretexts.org/Bookshelves/Microbiology/Book\%3A_ Microbiology_(Bruslind)/09\%3A_Microbial_Growth (accessed on 15 February 2021).

69. Weisblum, B. Erythromycin resistance by ribosome modification. Antimicrob. Agents Chemother. 1995, 39, 577-585. [CrossRef]

70. Zmantar, T.; Kouidhi, B.; Miladi, H.; Bakhrouf, A. Detection of macrolide and disinfectant resistance genes in clinical Staphylococcus aureus and coagulase-negative staphylococci. BMC Res. Notes 2011, 4, 453. [CrossRef]

71. Zmantar, T.; Kouidhi, B.; Hentati, H.; Bakhrouf, A. Detection of disinfectant and antibiotic resistance genes in Staphylococcus aureus isolated from the oral cavity of Tunisian children. Ann. Microbiol. 2012, 62, 123-128. [CrossRef]

72. Eady, E.A.; Ross, J.I.; Tipper, J.L.; Walters, C.E.; Cove, J.H.; Noble, W.C. Distribution of genes encoding erythromycin ribosomal methylases and an erythromycin efflux pump in epidemiologically distinct groups of staphylococci. J. Antimicrob. Chemother. 1993, 31, 211-217. [CrossRef]

73. Manyahi, J.; Matee, M.I.; Majigo, M.; Moyo, S.; Mshana, S.E.; Lyamuya, E.F. Predominance of multi-drug resistant bacterial pathogens causing surgical site infections in Muhimbili national hospital, Tanzania. BMC Res. Notes 2014, 7, 500. [CrossRef] [PubMed]

74. Tavajjohi, Z.; Moniri, R.; Khorshidi, A. Detection and characterization of multidrug resistance and extended-spectrum-betalactamase-producing (ESBL S) Pseudomonas aeruginosa isolates in teaching hospital. African J. Microbiol. Res. 2011, 5, $3223-3228$.

75. Motbainor, H.; Bereded, F.; Mulu, W. Multi-drug resistance of blood stream, urinary tract and surgical site nosocomial infections of Acinetobacter baumannii and Pseudomonas aeruginosa among patients hospitalized at Felegehiwot referral hospital, Northwest Ethiopia: A cross-sectional study. BMC Infect. Dis. 2020, 20, 92. [CrossRef]

76. Zhu, Y.; Chen, J.; Shen, H.; Chen, Z.; Yang, Q.W.; Zhu, J.; Li, X.; Yang, Q.; Zhao, F.; Ji, J.; et al. Emergence and rising of ceftazidime-avibactam resistant KPC-producing Pseudomonas aeruginosa in China: A molecular epidemiology study. medRxiv 2020, 1-43. [CrossRef]

77. Barsoumian, A.E.; Mende, K.; Sanchez, C.J.; Beckius, M.L.; Wenke, J.C.; Murray, C.K.; Akers, K.S. Clinical infectious outcomes associated with biofilm-related bacterial infections: A retrospective chart review. BMC Infect. Dis. 2015, 15, 223. [CrossRef] [PubMed]

78. Russotto, V.; Cortegiani, A.; Raineri, S.M.; Giarratano, A. Bacterial contamination of inanimate surfaces and equipment in the intensive care unit. J. Intensive Care 2015, 3, 54. [CrossRef] [PubMed]

79. Chaoui, L.; Mhand, R.; Mellouki, F.; Rhallabi, N. Contamination of the surfaces of a health care environment by multidrug-resistant (MDR) bacteria. Int. J. Microbiol. 2019, 2019, 3236526. [CrossRef]

80. Nadell, C.D.; Xavier, J.B.; Foster, K.R. The sociobiology of biofilms. FEMS Microbiol. Rev. 2009, 33, 206-224. [CrossRef] [PubMed]

81. Savage, V.J.; Chopra, I.; O'neill, A.J. Staphylococcus aureus biofilms promote horizontal transfer of antibiotic resistance. Antimicrob. Agents Chemother. 2013, 57, 1968-1970. [CrossRef]

82. Madsen, J.S.; Burmølle, M.; Hansen, L.H.; Sørensen, S.J. The interconnection between biofilm formation and horizontal gene transfer. FEMS Immunol. Med. Microbiol. 2012, 65, 183-195. [CrossRef] [PubMed] 